\title{
Improving the analysis of fatty acids using a combination of gas chromatography and $\mathrm{Ag}^{+}$liquid chromatography ${ }^{2}$
}

\author{
M. Czauderna ${ }^{1}$, J. Kowalczyk, K. Korniluk and I. Wąsowska \\ The Kielanowski Institute of Animal Physiology and Nutrition, Polish Academy of Sciences \\ 05-110 Jabłonna, Poland
}

\begin{abstract}
A method is proposed for routine determination of fatty acids (FAs), including conjugated fatty acids, in the liver of rats and sheep using gas-liquid chromatography (GLC) and $\mathrm{Ag}^{+}$-HPLC. The proposed procedure includes new methods for saponification carried out at room temperature and extraction of free FAs. The obtained free FAs are methylated in an acid-base catalyzed procedure. Due to simultaneous fractionation of methylated FAs using GLC and $\mathrm{Ag}^{+}-\mathrm{HPLC}$, the accuracy and sensitivity of the procedure is improved (especially for conjugated linoleic acids).
\end{abstract}

KEY WORDS: fatty acids, conjugated dienes, gas-liquid, silver ion chromatography

\section{INTRODUCTION}

Characterization of the complex lipid fraction in food by its fatty acid me-thyl esters (FAMEs) is a commonly accepted practice, particularly in the nutritional and biomedical fields. No single method is presently able to resolve all positional and geometric isomers of mono- and polyunsaturated fatty acids (MUFA, PUFA), conjugated linoleic acid isomers (CLA), saturated and branch-chain fatty acids (FAs). Capillary gas-liquid chromatography (GLC) is a widely used analytical technique, but liquid chromatographic methods are also receiving increased attention. The major objective of the current work was to develop a method for hydrolysis and derivatization of FAs. Attention has also been paid to improving the quantification of complex mixtures of FAs in the liver of rats and sheep. Therefore, long-capillary GLC and silver ion liquid chromatography ( $\mathrm{Ag}^{+}-$ HPLC) were adapted to analyse complex mixtures of FAs, as well as $\mathrm{CLA}^{2}$ isomers and other FAs containing conjugated double bonds (CFA).

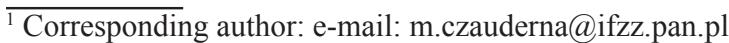

${ }^{2}$ the profile of CLA isomer mixture was presented previously (Czauderna et at., 2003)
} 


\section{MATERIAL AND METHODS}

Two groups of 7 female Wistar rats each, 8 weeks of age were housed individually as described previously (Czauderna et al., 2004). Briefly, rats were fed a control diet or a diet enriched with $2 \%$ of a CLA isomer mixture and $2 \mathrm{ppm}$ Se (as $\mathrm{Na}_{2} \mathrm{SeO}_{4}$ ). After 28 days the rats were killed and their livers were removed.

Sample preparation and saponification. Liver samples were frozen, lyophilized and the obtained residue was stored at $-20^{\circ} \mathrm{C}$ until analysed. In vials, finely powdered liver samples $(\sim 50 \mathrm{mg})$ were treated with a mixture of $2 \mathrm{ml}$ of $2 \mathrm{M} \mathrm{KOH}$ in water, 2 $\mathrm{ml} 1 \mathrm{M} \mathrm{KOH}$ in methanol, and $50 \mu \mathrm{l}$ of BHT in methanol $(20 \mathrm{mg} / \mathrm{ml})$. The mixture was then vigorously mixed in a closed vial and heated under argon at $95^{\circ} \mathrm{C}$ for 10 $\mathrm{min}$, cooled for $10 \mathrm{~min}$ at room temperature, and sonicated for $10 \mathrm{~min}$. The solution was protected from light and stored in a sealed vial at $22-25^{\circ} \mathrm{C}$ overnight.

Extraction of free FAs. To the hydrolysate in the vial, $3 \mathrm{ml}$ of water were added with vigorous mixing. Next, the solution was acidified with $4 \mathrm{M} \mathrm{HCl}$ to $\mathrm{pH} 1-2$ and free FAs were extracted four times with $3 \mathrm{ml}$ of dichloromethane (DCM). The lower DCM layer was dried with $0.1 \mathrm{~g}$ of $\mathrm{Na}_{2} \mathrm{SO}_{4}$. To avoid any loss of free FAs, extraction was repeated 4 times using $3 \mathrm{ml}$ of $\mathrm{n}$-hexane. The upper $\mathrm{n}$-hexane layer was then combined with the DCM layer and the organic solvents were removed under a stream of argon (Ar).

Preparation of fatty acid methyl esters. To the residue, $2 \mathrm{ml}$ of $2 \mathrm{M} \mathrm{NaOH}$ in me-thanol and $50 \mu \mathrm{l}$ of BHT in methanol $(20 \mathrm{mg} / \mathrm{ml})$ were added and mixed, flushed with $\mathrm{Ar}$, and reacted for $1 \mathrm{~h}$ at $80^{\circ} \mathrm{C}$. After cooling, $2 \mathrm{ml}$ of $25 \% \mathrm{BF}_{3}$ in methanol were added to the mixture, flushed with Ar, and again heated for $1 \mathrm{~h}$ at $80^{\circ} \mathrm{C}$. To the cooled reaction mixture, $5 \mathrm{ml}$ of water were added and FA-MEs were extracted with $5 \mathrm{ml}$ of $\mathrm{n}$-hexane. The clear supernatant was transferred to a vial. FA-MEe were separated by GLC, FAs containing conjugated double bonds, by isocratic liquid chromatography $\left(\mathrm{Ag}^{+}-\mathrm{HPLC}\right)$ with photodiode array detection (DAD) at $234 \mathrm{~nm}$.

Analytical conditions. The analyses were performed on an Agilent $6890 \mathrm{~N}$ GC equipped with CP7489 fused silica capillary column $(100 \mathrm{~m} \times 0.25 \mathrm{~mm}$ i.d. $\times 0.2$ $\mu \mathrm{m}$ film thickness; Varian, USA) and FID. Split injection was performed using an Agilent 7683 autosampler; $\mathrm{Ag}^{+}$-HPLC equipment as previously described (Czauderna et al., 2003) (mobile phase: n-hexane:acetonitrile -99.915:0.085, v/v; column temperature $31^{\circ} \mathrm{C}$; flow-rate $-1.35 \mathrm{ml} / \mathrm{min}$ ).

\section{RESULTS AND DISCUSSION}

A chromatogram of FA-MEs standards is shown in Figure 1. Separation is satisfactory except for $c 6 \mathrm{C} 18: 1$ and $c 7 \mathrm{C} 18: 1^{2}$ and $\mathrm{C} 20: 0$ and t9t12t18C18:3. 


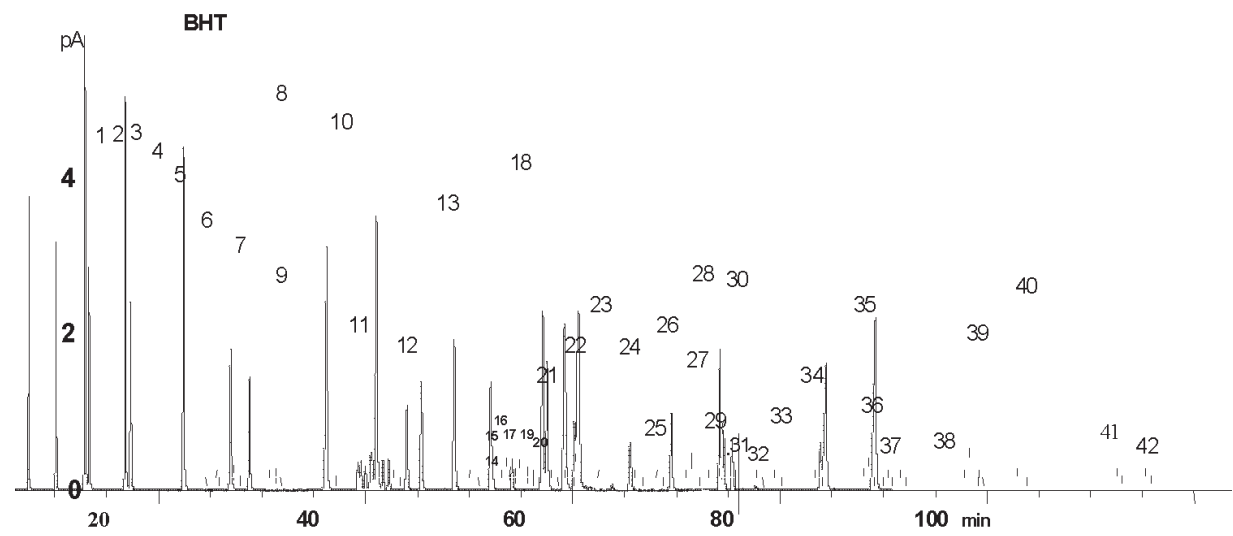

Figure 1. A chromatogram of FA-MEs ${ }^{3}$. The column was operated at $70^{\circ} \mathrm{C}$ for $4 \mathrm{~min}$, then temperature programmed to rise by $12^{\circ} \mathrm{C} / \mathrm{min}$ to $150^{\circ} \mathrm{C}$, held for $6 \mathrm{~min}$, then by $8^{\circ} \mathrm{C} / \mathrm{min}$ to $168^{\circ} \mathrm{C}$, held for $27 \mathrm{~min}$, next by $0.75^{\circ} \mathrm{C} / \mathrm{min}$ to $190^{\circ} \mathrm{C}$, held for $10 \mathrm{~min}$, then by $1.8^{\circ} \mathrm{C} / \mathrm{min}$ to $210^{\circ} \mathrm{C}$, held for $15 \mathrm{~min}$, next by $6^{\circ} \mathrm{C} / \mathrm{min}$ to $234^{\circ} \mathrm{C}$, held for $4 \mathrm{~min}$, then by $6^{\circ} \mathrm{C} / \mathrm{min}$ to $236^{\circ} \mathrm{C}$, held for $24 \mathrm{~min}$. Peaks: 1 - C8:0; 2- C9:0; 3- C10:0; 4- C11:0; 5- C12:0; 6 - C13:0; 7 - C14:0; 8 -C14:1; 9 - C15: $0 ; 10-\mathrm{C} 16: 0 ; 11-c 9 \mathrm{C} 16: 1 ; 12-\mathrm{C} 17: 0 ; 13-\mathrm{C} 18: 0 ; 14-t 6 \mathrm{C} 18: 1 ; 15-t 9 \mathrm{C} 18: 1 ; 16-t 11 \mathrm{C} 18: 1$; 17- $c 6 \mathrm{C} 18: 1+c 7 \mathrm{C} 18: 1 ; 18-c 9 \mathrm{C} 18: 1 ; 19-c 11 \mathrm{C} 18: 1 ; 20-c 12 \mathrm{C} 18: 1 ; 21-\mathrm{C} 19: 0 ; 22-$ $t 9 t 12 \mathrm{C} 18: 2 ; 23-c 9 c 12 \mathrm{C} 18: 2 ; 24-\mathrm{C} 20: 0+t 9 t 12 t 15 \mathrm{C} 18: 3 ; 25-c 6 c 9 c 12 \mathrm{C} 18: 3 ; 26-c 11 \mathrm{C} 20: 1$; 27- c9c12c15C18:3; 28 - c9t11CLA; $29-c 11$ t13/t11c13CLA + c8t10/t8c10CLA; 30 $t 10 c 12 \mathrm{CLA}+\mathrm{C} 21: 0 ; 31-c c$ CLA; 32- ttCLA; $33-c 11 c 14 \mathrm{C} 20: 2 ; 34-\mathrm{C} 22: 0 ; 35-c 13 \mathrm{C} 22: 1$; $36-c 11 c 14 c 17 \mathrm{C} 20: 3 ; 37-c 5 c 8 c 11 c 14 \mathrm{C} 20: 4 ; 38-c 5 c 8 c 11 c 14 c 17 \mathrm{C} 20: 5 ; 39-\mathrm{C} 24: 0$; 40 - $c 15 \mathrm{C} 24: 1 ; 41-c 7 c 10 c 13 c 16 c 19 \mathrm{C} 22: 5 ; 42-c 4 c 7 c 10 c 13 c 16 c 19 \mathrm{C} 22: 6$

${ }^{3}$ abbreviations for $c i s$ and trans: $c$ and $t$, respectively

Using the temperature program from 70 to $236^{\circ} \mathrm{C}$ permitted separation of shortchain to very-long-chain saturated FAs (C24:0), as well as MUFA, PUFA and CLA isomers. Fatty acids, as FA-MEs, were also identified in the liver of rats fed a control diet and a diet enriched in Se and CLA. No peaks corresponding to endogenous liver species co-eluted with FA-MEs peaks of calibration standards (Figure 1). Detailed analysis of the mixture profile of methylated CLA and CFA was performed using $\mathrm{Ag}^{+}-$ HPLC. UV absorption spectra of CLA isomers in a standard and in rat livers bear close resemblance. The obtained results indicate that all integrated CLA isomer peaks in the biological sample are "pure" ( 100\%) in the applied UV range (from 205 to $280 \mathrm{~nm}$ ) and free from the presence of unidentified species and noise fluctuations.

\section{CONCLUSIONS}

The presented procedure provides a universal method for gentle saponification using a mixture of $\mathrm{KOH}$ in water and methanol for $\sim 12 \mathrm{~h}$. As the saponification is 
carried out at room temperature, the method eliminates the risk of isomerization (e.g., $t 9 \mathrm{C} 18: 1$ into $c 6 \mathrm{C} 18: 1)$ and PUFA degradation. Addition of an extra $3 \mathrm{ml}$ of water to hydrolysates and then the use of DCM and n-hexane for extraction of free FAs improved the formation yield of FA-MEs. A long capillary GLA column and the proposed column temperature program seem to be the best compromise for satisfactory fractionation of physiologically important FAs and duration of GCL analysis. Excellent characterization of conjugated FAs was obtained using $\mathrm{Ag}^{+}$HPLC since DAD distinguishes only FAs containing conjugated double bonds (like CLA or CFA), while other FAs are undetectable.

\section{REFERENCES}

Czauderna M., Kowalczyk J., Niedźwiedzka K.M., Wąsowska I., Pastuszewska B., Bulska E., Ruszczyńska A., 2004. Liver and body mass gain, content of CLA isomers and other fatty acids in the liver of rats fed CLA isomers and selenium. J. Anim. Feed. Sci. 13, 353-369

Czauderna M., Kowalczyk J., Wąsowska I., Niedźwiedzka K.M., 2003. Determination of conjugated linoleic acid isomers by liquid chromatography and photodiode array detection. J. Anim. Feed Sci. 12, 269-382

\section{STRESZCZENIE}

Udoskonalenie metody oznaczania kwasów tluszczowych wykorzystując jednocześnie chromatografię gazową i $\mathrm{Ag}^{+}$chromatografię cieczową

Opisano czułą i selektywną procedurę oznaczania kwasów tłuszczowych (FA) w wątrobie owiec i szczurów. Opracowano nową metodę hydrolizy w temperaturze pokojowej i metodę ekstrakcji wolnych FA z hydrolizatu; metylowe pochodne FA uzyskano stosując zasadowo-kwasowo katalizowaną reakcję upochodnienia. Dzięki jednoczesnej analizie pochodnych FA metodą chromato-grafii gazowej i $\mathrm{Ag}^{+}$-HPLC uzyskano poprawę dokładności i selektywności oznaczania FA. 